Crowding out or crowding in?

Public and private transfers in Germany

Anette Reil Held

72-2005

June 2005 


\title{
Crowding out or crowding in? Public and private transfers in Germany
}

\author{
Anette Reil-Held* \\ Mannheim Research Institute for the Economics of Aging (MEA) \\ University of Mannheim
}

\begin{abstract}
Intergenerational support exchanges are of particular interest in Europe's ageing populations. This paper focuses on the relationship between private and public financial transfers to and from the elderly. Based on German data we find that the giving of private transfers is influenced by public transfers. The close link between public transfers to the elderly and the financial support they give to others represents an inefficient backflow of pay-as-you-go financed pensions to the young generation. This mechanism can be interpreted as a private compensation device for the generations. We can also show that at the same time the receipt of public transfers by the elderly crowd-out private financial support they would have received otherwise in the German welfare state.
\end{abstract}

\author{
Address: \\ Mannheim Research Institute \\ for the Economics of Aging (MEA) \\ University of Mannheim \\ L 13,17 \\ D - 68131 Mannheim \\ Phone +49621 181-1859 \\ Fax +49621 181-1863 \\ reil-held@mea.uni-mannheim.de
}

\footnotetext{
* I want to thank Axel Börsch-Supan, Karsten Hank, Joachim Winter, Hendrik Jürges and the participants of the EAPS/INED workshop in Paris for their valuable comments, especially John Henretta for his discussion and Emily Grundy for all her support. I am grateful to the Gesamtverband der Deutschen Versicherungswirtschaft, the state of Baden-Württemberg and the Deutsche Forschungsgemeinschaft within the Sonderforschungsbereich 504 for financial support.
} 


\section{Introduction}

Private intergenerational support has received increasing attention in in the analysis of the effects of an aging population on the social security systems. Private transfers interact with social security programs. If private and public transfers are close substitutes, an expansion of public transfers could lead to a reduction in private transfers, diluting the effectiveness of any programme. Wider social security coverage might for example cause children to reduce private transfers to their retired parents ("crowding out"). The goal of this paper is to investigate the relationship between public and private transfers by analysing German data. While intergenerational support can take many different forms like informal loans, transfers in kind or assistance with housework or child-care, this analysis concentrates on private financial transfers.

First we examine the relationship between private transfers given by the elderly and the public transfers they receive. We want to find out if the relatively generous public pay-as-you-go pensions which are financed by the younger generation are paid back to them as private transfers by the elderly. This would be in line with Barro (1974) who argued that the generations of a family dynasty are altruistically linked. Parents consider the welfare of their children when maximizing their own utility. Therefore they might react to an intergenerational reallocation of resources through state interventions by adapting their private intergenerational transfers. For instance, parents could compensate an increase of public payas-you-go financed pensions by increasing their private financial transfers to their offspring. Indeed, German data show that public transfers positively affect the willingness to pay private transfers. ${ }^{1}$ While economists consider this to be an inefficient detour system, sociologists argue that generous public transfers allow the elderly to give financial resources to their children and therefore strengthen solidarity within the family (Kohli 1993). Because reciprocity is an important determinant of transfer behaviour, the elderly can expect to receive support from their children in return. This is discussed in the literature as "crowding in" process (Künemund and Rein 1999).

Secondly, this paper adds to the discussion about "crowding in" and "crowding out" by providing new empirical evidence about the substitution of public for private financial transfers to the elderly . Even though financial transfers mainly flow from old to young, we observe financial support towards the elderly too. It is often argued that a well developed welfare state like in Germany reduces, i.e. "crowds out" this private help. However, sociologists

\footnotetext{
${ }^{1}$ See Reil-Held (2002). The robustness of these results based on 1993 data will be checked in this paper by replicating the analysis with newer data from 1998.
} 
point out that there is a "crowding in" process which represents a complementary relationship between public and private transfers by taking a broader view than looking at financial help only (Attias-Donfut and Wolff 2000). Public transfers allow the elderly to give financial resources to their children who support their parents in return by providing help or attention.

In this paper we take a narrower perspective looking at financial transfers only and find new empirical support for the crowding out hypothesis. We find that elderly receiving more public transfers are less likely to receive private financial support. Of course, this does not necessarily contradict the crowding in hypothesis but points to the coexistence of both. However, for the design of social security systems the crowding out of private financial transfers by public support has to be kept in mind.

The paper is structured as follows. In the next section we provide the economic background and summarize former empirical evidence about the relationship between public and private transfers. Section 3 begins with an empirical description of the private transfer flow in Germany. After that the impact of public transfers on the transfer giving of the elderly is analysed. In section $4 \mathrm{a}$ test of the crowding out hypothesis is introduced by investigating private transfers received by the elderly. Finally, we end with some concluding remarks.

\section{Public and private transfers: Background and former evidence}

\subsection{Why should public transfers influence private transfer giving?}

One explanation as to why public transfers received by the elderly could have a positive impact on the giving of private transfers to the young was delivered by Barro $(1974,1978)$. He pointed out that financial transfers from parents and children aim at neutralizing the efforts of the state to change the intergenerational allocation of resources, such as an increase in government debt for instance. The underlying thought is that the generations of a family ("dynasty") are altruistically linked. Therefore, the time horizon underlying their decisions goes beyond their own expected length of life and includes the utility of their offspring as well. In this case, parents might react, for example to an increase in their pay-as-you-go financed pensions, by increasing their financial support to the children in order to compensate them for the resulting contribution burden. This compensation payment can be realized either as a transfer inter vivos or as a bequest. This potential connection between public and private transfers will be empirically examined in section 3 . 


\subsection{Public and private transfers: Crowding out or crowding in?}

Potential substitution effects between public and private transfers are relevant for social policy. Designers of social security programs have to ask if "private interfamily transfers take up the slack if social security programs are reduced" (Cox and Jakubson 1995). The crowding out hypothesis with respect to exchanges between generations assumes that a more generous welfare system weakens family solidarity: the supply of public pensions and services for elderly people crowd out familial help because children do not need to assist their parents when the state provides adequate income and services (Künemund and Rein 1999).

However, from their survey of the literature, Künemund and Rein (1999) conclude that the crowding out argument is often used but empirical tests about the negative impact of generous welfare state spending on family solidarity are hardly ever documented. From a sociological perspective crowding out of familial support is not self-evident. As reciprocity is an important motive for giving, ${ }^{2}$ a generous welfare state enables the elderly to make gifts to their children which in turn creates incentives for the children to support the elderly. ${ }^{3}$ The strengthening of the family relationship permitted by sufficient public resources is described as "crowding in" (Künemund and Rein 1999). Daatland (2004) adds a further argument for a complementary relationship between public and private help. He argues that the welfare state might stimulate family efforts by sharing the burden.

The assumption of a substitutive relationship between public and private transfers is rejected by an analysis of Attias-Donfut and Wolff (2000) based on French data. For example they estimated the effect of public transfers on private transfers with respect to the financial support given to children and found a strong positive correlation between the receipt of public transfers and the probability of receiving financial help from parents. This points to complementarity between private and public transfers.

On the other hand, they also simulated how a 10 percent reduction of retirement pensions would affect private support. As a result, retired people decrease the amount of financial support to their children who have in turn to increase the financial support to their parents to let them maintain an adequate standard of living. The 10 percent decrease of public pensions

\footnotetext{
2 Künemund and Rein (1999) investigate the impact of giving and receiving based on the so-called Five Nation Study which is a survey conducted for the Commonwealth Fund in 1991. It includes Canada, Japan, United Kingdom, Germany and the USA. They provide evidence for the effect of reciprocity: those who give are more likely to receive.

3 They assert another argument: Welfare state spending does reduce the "burden" of family relationships. "When elderly people have sufficient resources of their own, they are not forced by necessity to rely on their families. Therefore interactions focused on intimacy and closeness have the potential to develop." (Künemund and Rein 1999)
} 
leads to an increase of 6.9 per cent in the probability of financial gifts from the middle generation to their parents and a reduction of 2.1 per cent in the probability of financial help from the older to the middle generation (Attias-Donfut and Wolff 2000).

Künemund and Rein (1999) used an international comparison in order to test the existence of crowding in versus crowding out. Based on the so-called Five-Nations-Study they find that Germany is the country where elderly people are most likely to receive help from their children living outside the household. Nearly 90 per cent report that they receive at least one of four types of help. ${ }^{4}$ By contrast, the UK is the country where help is received the least often. Since the welfare systems in the countries included differ substantially, Germans are expected to get less financial help than the elderly in the US for instance. ${ }^{5}$ Less need or help with money might result in a crowding in of services. The data show that the German case is a clear example of a generous social security system that does not lead to a crowding out of family solidarity in general: elderly do not even receive significantly less help with money as the crowding out hypothesis would suggest. Furthermore, Germany has the lowest percentage of elderly who do not receive any help at all. Künemund and Rein (1999) conclude that these findings do not support the crowding out hypothesis.

Daatland (2004) uses the OASIS data for an international comparison of help profiles. ${ }^{6} \mathrm{He}$ can neither find support for crowding-out nor what he calls the 'strong variant' of crowding in where public services are expected to increase family help. Instead the findings fit with a weaker variant of crowding in, "namely that a generous welfare state allows the family to reorient their responsibility towards tasks and needs that are not well covered (and possibly create a lower burden for the children)." This would not only lead to an increase of total care levels but to more independent intergenerational relationships as well.

Economists stress the importance of the underlying bequest motive for the process of crowding out. In general we distinguish between altruism and trading of benefits as the two main transfer motives (e.g. Cox 1987). Altruism is based on familial care and the moral duty to help. In altruistic models parents consider the utility of their children when maximizing their

\footnotetext{
${ }^{4}$ The four types of help in this study are help when ill, take care of house, help with transport and help out with money.

${ }^{5}$ The differences between the welfare can be measured by a higher pension replacement rate and a lower poverty rate in Germany.

${ }^{6}$ The OASIS project includes Norway, England, Germany, Spain and Israel.
} 
own utility (Becker 1974, Barro 1974). The exchange motive assumes that one gives to others because he expects to get something back in return. ${ }^{7}$

The two transfer motives have different implications for the crowding out process. Purely altruistically motivated private transfers are crowded out by public transfers as it does not matter from whom the person in need receives help. But the effect is a priori unclear in exchange models. It depends on the difference between the parent's and the child's marginal utility of consumption when no transfers occur (Cox and Jakubson 1995). On a large scale altruistically motivated transfers would therefore dampen or even neutralize the distributional impact of public transfers while exchange motivated transfers can reinforce the effects of public transfers. In Cox and Jakubson's empirical analysis about the distributional impact of anti-poverty programs in the US they take the response on private transfers into account. Their findings suggest an exchange rather than altruistic motive for private transfers. This indicates that the effect of public transfers can be magnified by private transfer behaviour.

In total, the international empirical evidence about the prevalence of altruism is very mixed. ${ }^{8}$ For Germany, an empirical analysis of Jürges (1999) does not lead to a clear result which he interprets as an indication for the presence of both exchange and altruistically motivated transfers. On the other hand survey results about the motives of familial support do indicate an altruistic notion. Kohli et. al. (2000a) infer a social consensus about indigent relatives what they interpret as altruism. About 90 percent of the respondents in the Ageing Survey claim that they always would help their relatives if they need their support. With respect to inheritances Wilk (1995) found in group discussions too, that altruism seems to dominate the notion of exchange in Germany.

\section{The impact of public transfers on private transfers in Germany}

\subsection{The flow of transfers inter vivos in Germany}

As a basis for investigating the relationship between public and private transfers in Germany the flow of private intergenerational transfers is briefly presented in this section. In the 1990s about one third of the elderly payed a transfer to the younger generation of about 5000 and $7000 \mathrm{DM}^{9}$. The quantitative significance of private transfers can be illustrated by aggregating

\footnotetext{
${ }^{7}$ There are different forms of exchange models in the literature: e.g. Cox (1987) considers an exchange of services and inner familial credit markets, Kotlikoff and Spivak (1981) elaborate the family as an annuity market while Bernheim et. al. (1985) use a game theoretical approach to explain transfer behaviour as "strategic bequests".

${ }^{8}$ See e.g. Masson and Pestieau 1997, Reil-Held 2002 for an overview.

${ }^{9}$ The results vary because of different survey techniques and samples in the different data sets. See Reil-Held (2002) for an overview about private transfer data.
} 
the transfer volume from old to young. An aggregation based on the transfer data in the socalled "Ageing Survey" yields a transfer volume of 9 percent of total pension payments which represents an average transfer payment by each pensioner of about one sixth of his pension income (Kohli 1998). ${ }^{10}$

Private transfers in the opposite direction, namely from the young to the old generation are rather unusual. Figure 1 shows the total flow of financial and instrumental intergenerational support based on the Ageing Survey. Instrumental help includes assistance with housework, shopping or small repairs. The percentage numbers in figure 1 represent the share of each population group, giving support to another generation.

Figure 1: Transfers and Help exchanges among persons aged 40 to 54 years 70 to 85 years
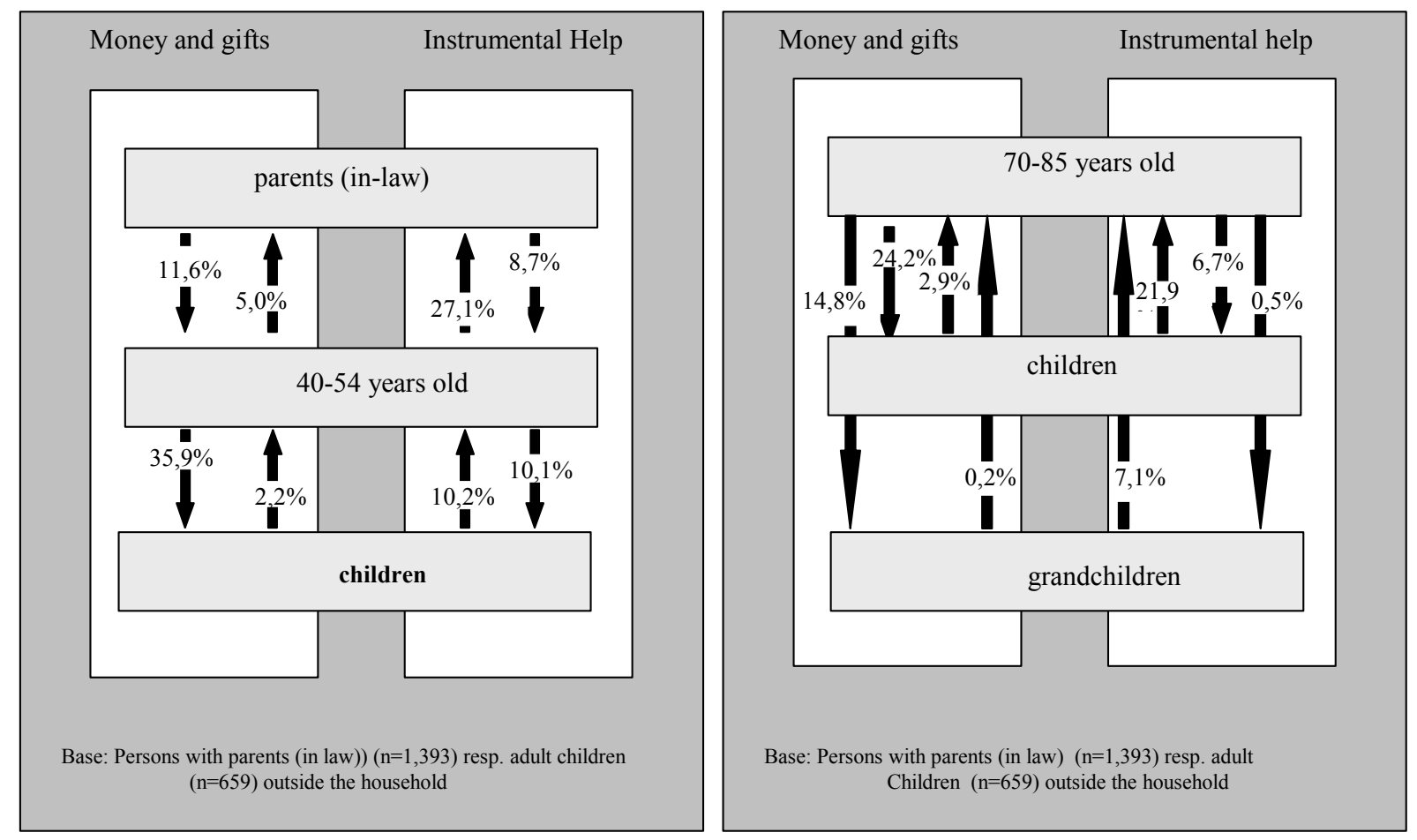

Source: Kohli et. al. (2000a), p. 193,194

The left hand side of figure 1 refers to the middle generation of 40 to 54 year old persons. The transfer pattern is clear: financial support and gifts are given from the middle generation to their grown-up children outside the household while we observe only few transfers from the children to their parents. The transfers from the middle generation to their offspring are clearly higher than the middle generation receives from their parents. However, the direction

\footnotetext{
${ }^{10}$ The Ageing Survey was conducted in 1996 by the sociological research group FALL. The survey includes rich information about the living conditions of persons aged 40 to 85. See Kohli et. al. (2000a) for a description of the data and results.
} 
of instrumental help is very different. While non-financial support is much more balanced between the middle generation and their children, the 40 to 54 years old sample persons provide more support to their parents than they receive from them.

The pattern that can be seen on the right hand side of figure 1 referring to the 70 to 85 years old respondents is very similar. Financial transfers mainly flow towards the younger generation. About one quarter of the sample members aged between 70 and 85 give a financial transfer to at least one of their children and more than 20 percent to their grandchildren. The other way round, only 3 percent of the elderly receive financial aid from their children and hardly anything at all from their grandchildren. On the other side instrumental help goes from the younger to the older generation. While one fifth of the elderly receives such a support by their children, only 7 percent of the elderly are helping their children in such a way. The relation to the grandchildren is similarly unbalanced. Although the elderly have more time at hand because they are no longer employed, they rather give money to their children. The children have less time than their parents but support their parents nevertheless. This can be interpreted as a hint to the complex relationship between resources and needs as well as the underlying specific motivations of intergenerational aid (Kohli et. al. 2000a).

\subsection{The relationship between public and private transfers in Germany}

In the following section we add new empirical evidence to the discussion about crowding in and crowding out by investigating the relationship between public and private transfers from two perspectives: First we look at the influence of public transfers on the giving of private transfers of the elderly. A positive impact of public transfers on private transfer payments would be in line with the crowding-in argument and with the existence of a compensation process between the generations as Barro suggested (see section 2.2.). In the second part we examine the receipt of financial private support by the elderly to test the crowding-out hypothesis. Ideally, one would need adequate longitudinal data for the analysis. As such data is currently not available we will exploit the variation of the composition of household income in Germany for our empirical analysis. This procedure supplements the evidence gained so far by international comparisons. The central variable to explain transfer behaviour in the subsequent analysis will be the fraction of public transfers in total household income. We test the crowding out hypothesis in a narrow sense, i.e. restricted to financial support, by estimating if those elderly who receive more public transfers receive less private financial 
help. Before we present the empirical findings we shortly describe the underlying data in the next section.

\subsubsection{The data}

We base our analysis on the German Income and Expenditure Survey 1998 (EVS "Einkommens- und Verbrauchsstichproben"). ${ }^{11}$ The EVS has been collected by the Federal Statistical Office every five years since 1963. The main purpose of the EVS is to comprehensively examine the economic and social situation of private households in order to construct statistical measures for the government, such as various price indexes, poverty measures and measures of wealth accumulation (Euler 1992). Data on income, expenditures, home ownership, wealth and debt are collected. The EVS 1998 is provided to researchers as a "scientific use file" which contains nearly 80 percent of the original sample. In total the data from 49,720 households is included. The large sample size allows to analyse private transfers received by the elderly on a sound statistical basis. Most surveys suffer from the lack of variation because especially the share of elderly receiving private financial transfers is small. ${ }^{12}$

During the survey period each household keeps a detailed diary in which all income sources and expenditures for the most important areas are recorded for three months. This leads to a very good coverage of income and expenditures. Private transfers are covered as an income and an expenditure category "financial support to/from other private households". While the EVS data is very rich with respect to sample size and detailed recording, the data shows some restrictions which have to be mentioned too. Firstly, the EVS data do not allow us to distinguish between voluntary private transfers and alimonies which have to be paid by the transfer giver. Therefore we restrict the sample in the following analysis to households whose head is at least 65 years old as legally enforced payments (due to divorce or illegitimate children for instance) do not occur very often in this age group. The restriction to this agegroup still leaves a sample size of 8586 households. Secondly, we cannot distinguish intergenerational from other private transfers as one does not know from whom exactly the transfer comes or to whom it goes, e.g. from parents to children or to/or from a non-relative. Furthermore, bequests cannot be distinguished from transfers inter vivos. This distinction would be helpful for the analysis as the underlying motivation for bequests remains unclear. They can either happen accidentally or intentionally. But again, the restriction to the age-

\footnotetext{
${ }^{11}$ See Börsch-Supan, Reil-Held und Schnabel (2001) for a comprehensive description of the EVS.

12 See figure 1 or Croda (1999) for an analysis based on SOEP data.
} 
group 65 and older excludes a large proportion of bequest receipt which more often occur in younger age-groups.

Overall, the comprehensiveness of the EVS data with respect to income sources and expenditures, together with the large sample size is a solid basis to conduct the following new approach to investigate transfer behaviour.

\subsubsection{Private transfer giving of the elderly and public transfers}

Due to the survey method - the households are obliged to keep household books - and the non-censoring of the transfer amounts which is common in most other surveys, private transfers are recorded in the EVS data very comprehensively. In total, 62 percent of the households with a head aged 65 or older report a transfer to another private household in 1998. ${ }^{13}$ On average 3157 DM was paid, or 4960 DM per transfer-giving household. While there is barely a difference between the old and new German states ${ }^{14}$ in the percentage of households giving a transfer, transfer amounts are clearly higher in West-Germany (5227 DM) than in East-Germany (3473 DM). ${ }^{15}$ The distribution of the amounts transferred differs significantly which is in line with what was expected. The median transfer amount is 1856 $\mathrm{DM}$, ten percent of the transfers are smaller than $280 \mathrm{DM}$ and the top decile of the transfer distribution starts at 9800 DM. Figure 2 shows the fraction of households who gave financial support to other private households in 1998 by income quartile.

\footnotetext{
${ }^{13}$ This is registered as an expenditure category in the household book: "Alimony and other financial transfers to persons outside the household (cash gifts).

${ }^{14}$ About $62 \%$ of West and $66 \%$ of East German households are private transfer givers.

${ }^{15}$ See Kohli, Künemund, Motel and Szydlik (2000) for a comparison between East and West Germany.
} 
Figure 2: Transfer givers by income quartile

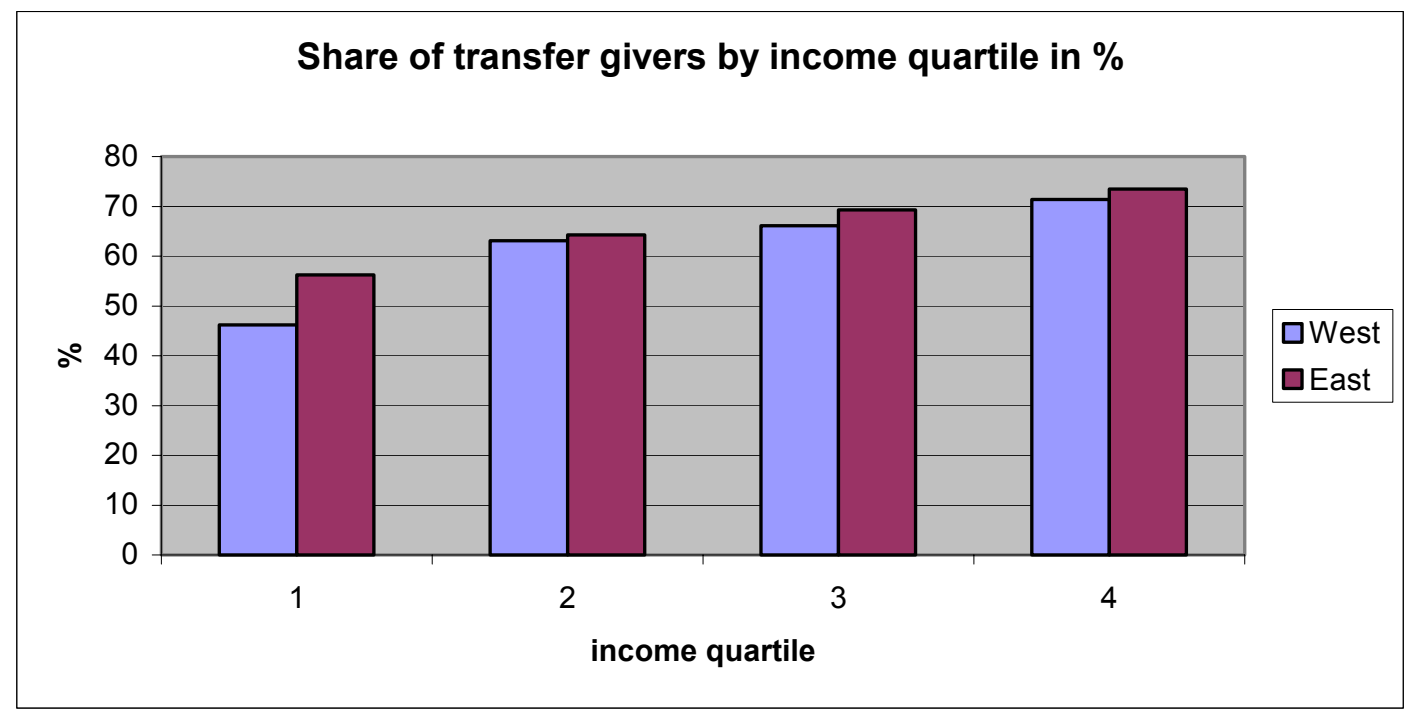

Note: Only household head aged at least 65. Source: Own calculations based on EVS 1998.

The higher the income, the higher the proportion of households making private payments. The fraction of households transferring money to others steadily increases over the income quartiles. But even in the lowest quartile, about half of the elderly households reported making private transfers. Unsurprisingly the same holds for the amount transferred while this pattern is more marked in the old than the new federal states, see figure 3.

\section{Figure 3: Transfer amounts by income quartile}

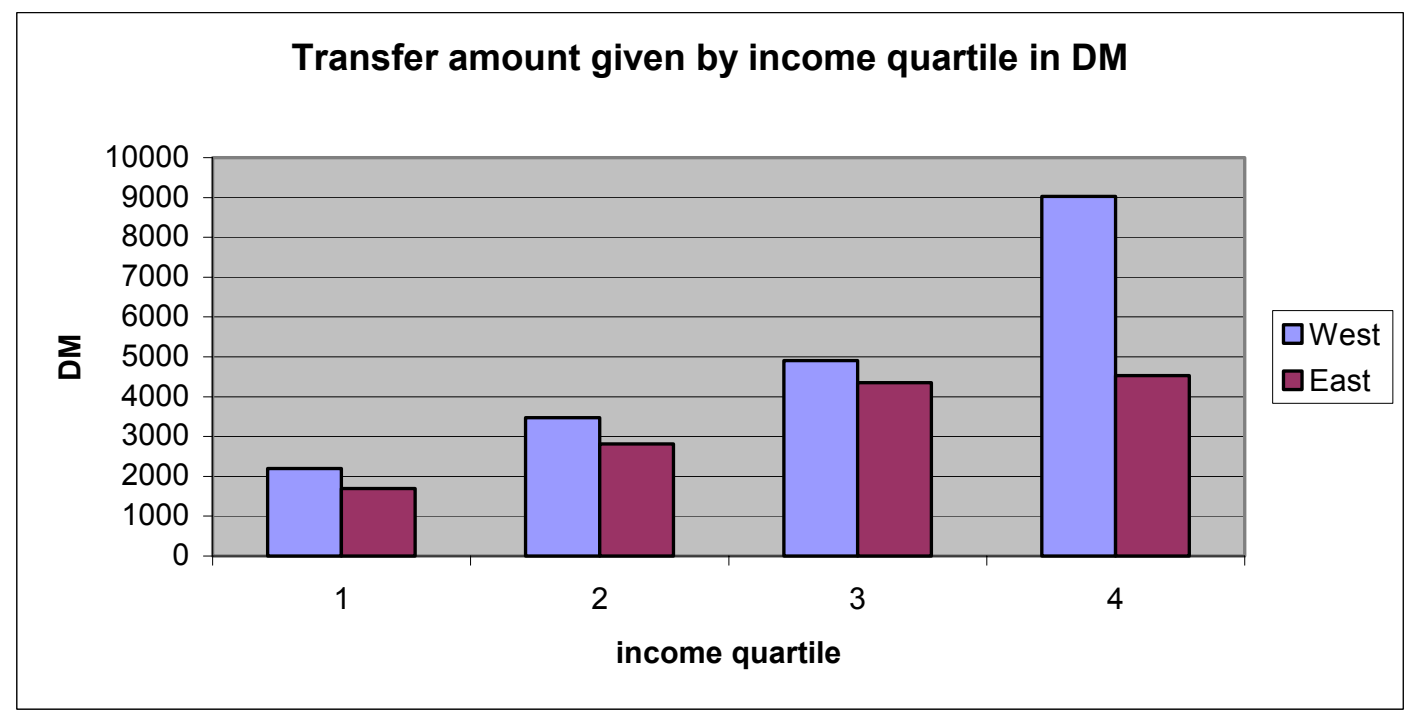

Note: Only household head aged at least 65. Source: Own calculations based on EVS 1998.

In order to address the direct link between public and private transfers we now look at how much public transfers contribute to the household income of the elderly. In this age group public transfers mainly consist of public pensions. Besides public pensions all other kinds of 
public financial support, such as social assistance or housing allowances, are subsumed in this category, too. While the gross income on average amounts to 3437 DM (West) and 2694 DM (East) per month, the average household received public transfers of 2912 DM or 2744 DM per month in the Western or Eastern part of Germany respectively. On average public transfers make up 82 percent of the household income in the old and 95 percent in the new states. With respect to transfer givers and non-givers a bivariate analysis shows no significant difference in the share of public transfers.

In the following estimation we will test the impact of the share of public transfers on the willingness to give private transfers while controlling for household income, i.e. we ask if public transfers directly determine the payment of private transfers. Public transfers that are financed by the working age generation through social security contributions and taxes are expected to be given back to them via private channels. Therefore our hypothesis is that households with a higher share of public pensions in their income package show a higher propensity to give private financial support.

To test this hypothesis we firstly use a probit model to estimate the probability of giving a transfer. Because we need to control for the most important socio-economic characteristics we have to include characteristics like age, gender, family status and financial wealth of the household heads in the model. Based on former evidence we expect the demographic characteristics to be less important than the economic conditions (e.g. Reil-Held 2002, AttiasDonfut and Wolff 2000). ${ }^{16}$

As we have seen that the transfer behaviour as well as the importance of public transfers in the income package differs between the old and the new federal states, we run the regressions for East and West Germany separately. In the following we mainly concentrate on the old states and show the estimation results for the new states in the appendix. Firstly, we present the results of the probit estimation to explain the probability of making a private transfer in table 1 . The dependent variable is a dummy variable, taking the value of 1 if a private household paid private transfers and 0 otherwise.

\footnotetext{
16 Bivariate analysis show for instance that women are more reluctant to financially support others because they live more often alone and have a lower income (Motel and Sydlik, 1999) while in multivariate analysis no gender differences can be found (Motel and Spieß, 1995; Motel and Szydlik, 1999). The results with respect to the family status are ambiguous. Single elderly effect transfers less often than couples (Motel und Szydlik, 1999). Other studies found that especially elder men and couples give transfers to their offspring. The age-effect is ambiguous, too. While Motel und Szydlik (1999) could not find a significant impact, Jürges (1999) shows a probability of transfer giving which is decreasing by age.
} 
In the following investigation of the transfer amount one has to consider that only amounts greater than zero in the transfer case and zero otherwise can be observed. ${ }^{17}$ Therefore we use a Tobit estimation for the transfer amount which takes care of the left censoring of the independent variable at $0 \mathrm{DM}^{18}$ The results are displayed in table 2 and refer to the same independent variables as in the probit estimation.

For both estimations, probit and tobit, three different specifications for public transfers have been used: (1) public transfers in DM, (2) share of public transfers in household income and (3) a Dummy-specification, representing firstly a public transfer share in income of 100 percent and secondly a public transfer share which is lower than 75 percent of income.

\footnotetext{
${ }^{17}$ The size of the transfers cannot be estimated with a simple regression because the transfer giving itself depend already on several circumstances, for instance the existence of potential recipients. If we would consider in the estimation only transfer givers, the results would be distorted because of this sample selection. In such a case one usually uses the two-step Heckman-estimation (see e.g. Green 1997). At first it is necessary to build a separate model for the decision to give a transfer (selection equation), for which one needs to find appropriate instrument variables, that are related to the probability to give a transfer but not to its amount. Unfortunately, in the EVS data set no such variables (like the presence of adult children) are available. Therefore the Heckman-estimation did not lead to satisfactory results.

${ }^{18}$ In the following estimation a logarithmic specification for the amounts given respectively received was choosen because this leads to a much better fit of the regression. As the logarithm of 0 is not identified the nontransfer payments have been set equal to one which is correspondingly used as the left-censoring point.
} 
Table 1: Determinants of transfer giving (West) ${ }^{19}$

\begin{tabular}{|c|c|c|c|c|c|c|}
\hline & \multicolumn{2}{|c|}{ Probit (1) } & \multicolumn{2}{|c|}{ Probit (2) } & \multicolumn{2}{|c|}{ Probit (3) } \\
\hline Variable & Coefficient & $\begin{array}{c}\text { z- } \\
\text { value }\end{array}$ & Coefficient & $\begin{array}{c}\mathbf{z -} \\
\text { value }\end{array}$ & Coefficient & $\begin{array}{c}\text { z- } \\
\text { value }\end{array}$ \\
\hline Age & -0.1472 & -2.06 & -0.1465 & -2.06 & -0.1412 & -1.99 \\
\hline Age squared & 0.0010 & 2.05 & 0.0010 & -.06 & 0.0009 & 1.99 \\
\hline Household size & -0.2624 & -4.63 & -0.2677 & -4.73 & -0.2740 & -4.84 \\
\hline Female & 0.1388 & 2.78 & 0.1309 & 2.62 & 0.1298 & 2.60 \\
\hline Never married & -0.4014 & -4.60 & -0.4104 & -4.17 & -0.4209 & -4.84 \\
\hline Widowed & -0.0644 & -0.85 & -0.0719 & -0.95 & -0.0803 & -1.06 \\
\hline Married & Reference & - & Reference & & Reference & \\
\hline Divorced & -0.4110 & -4.67 & -0.4263 & -4.86 & -0.4456 & -5.10 \\
\hline $\begin{array}{l}\text { Living } \\
\text { Separately }\end{array}$ & -0.2578 & -1.85 & -0.2978 & -2.15 & -0.3388 & -2.46 \\
\hline $\begin{array}{l}\text { Disposable } \\
\text { Income (log) }\end{array}$ & 0.3648 & 7.25 & 0.5503 & 14.55 & 0.5137 & 13.63 \\
\hline $\begin{array}{l}\text { Public transfers } \\
\text { (log) }\end{array}$ & 0.1929 & 4.28 & - & - & - & - \\
\hline $\begin{array}{l}\text { Public transfer } \\
\text { income share }\end{array}$ & & & 0.0030 & 3.57 & & \\
\hline $\begin{array}{l}\text { Share of public } \\
\text { transfers }=1 \text { (D) }\end{array}$ & - & - & - & - & -0.1043 & -2.73 \\
\hline $\begin{array}{l}1>\text { Share of publ } \\
\text { transf. }<0.75\end{array}$ & - & - & - & - & Reference & - \\
\hline $\begin{array}{l}\text { Share of public } \\
\text { transf.<0.75, D. }\end{array}$ & - & - & - & - & -0.1194 & -2.89 \\
\hline Financial wealth & $-4.03 e-08$ & -0.30 & $-5.57 e-08$ & -0.42 & $-1.01 e-07$ & -0.77 \\
\hline Homeowner & 0.1449 & 4.30 & 0.1473 & 4.38 & 0.1361 & 4.05 \\
\hline Constant & 2.8988 & 1.08 & 3.9620 & 1.49 & 4.1990 & 1.58 \\
\hline $\begin{array}{l}\text { Number of } \\
\text { observations }\end{array}$ & 6788 & & 6788 & & 6788 & \\
\hline LF $\operatorname{chi2(12)}$ & 379.99 & & 377.53 & & 377.15 & \\
\hline Pseudo R2 & 0.0422 & & 0.0418 & & 0.0417 & \\
\hline
\end{tabular}

Note: Own calculations based on the EVS 1998. Sample includes households with a head aged 65 and older. Sample estimates are weighted to represent the German population.

\footnotetext{
${ }^{19}$ See table 1a in the appendix for the estimation results based on the East sample.
} 
Table 2: Determinants of transfer amounts given (West) ${ }^{20}$

Tobit (1)

Tobit (2)

Tobit (3)

\begin{tabular}{|c|c|c|c|c|c|c|}
\hline Variable & Coefficient & $\begin{array}{c}\text { z- } \\
\text { value }\end{array}$ & Coefficient & $\begin{array}{c}\text { z- } \\
\text { value }\end{array}$ & Coefficient & $\begin{array}{c}\text { z- } \\
\text { value }\end{array}$ \\
\hline Age & -0.2728 & -1.06 & -0.2684 & -1.05 & -0.2517 & -0.98 \\
\hline Age squared & 0.0020 & 1.16 & 0.0020 & 1.15 & 0.0019 & 1.09 \\
\hline Household size & -1.0062 & -4.79 & -1.020 & -4.86 & -1.0414 & -4.96 \\
\hline Female & 0.4770 & 2.60 & 0.4498 & 2.46 & 0.4456 & 2.43 \\
\hline Never married & -1.4231 & -4.39 & -1.4431 & -4.46 & -1.4726 & -4.55 \\
\hline Widowed & 0.0191 & 0.07 & 0.0080 & 0.03 & -0.0202 & -0.07 \\
\hline Married & Reference & - & Reference & - & Reference & - \\
\hline Divorced & -1.2647 & -3.88 & -1.2948 & -3.98 & -1.3534 & -4.17 \\
\hline $\begin{array}{l}\text { Living } \\
\text { Separately }\end{array}$ & -0.0901 & -0.18 & -0.2078 & -0.41 & -0.3296 & -0.65 \\
\hline $\begin{array}{l}\text { Disposable } \\
\text { Income (log) }\end{array}$ & 1.5284 & 8.39 & 2.0611 & 15.29 & 1.9563 & 14.53 \\
\hline $\begin{array}{l}\text { Public } \\
\text { transfers (log) }\end{array}$ & 0.5372 & 3.28 & - & - & - & - \\
\hline $\begin{array}{l}\text { Public transfer } \\
\text { income share }\end{array}$ & - & - & 0.0091 & 3.02 & & \\
\hline $\begin{array}{l}\text { Share of public } \\
\text { transfers }=1, D \text {. }\end{array}$ & - & - & - & - & -0.2780 & -1.99 \\
\hline $\begin{array}{l}1>\text { Share of publ } \\
\text { transf }<0.75\end{array}$ & - & - & - & - & Reference & - \\
\hline $\begin{array}{l}\text { Share of public } \\
\text { transf }<0.75 \text {, D }\end{array}$ & - & - & - & - & -0.3450 & -2.33 \\
\hline $\begin{array}{l}\text { Financial } \\
\text { wealth }\end{array}$ & $-1.62 e-07$ & -0.43 & $-1.81 e-07$ & -0.38 & $-3.22 e-07$ & -0.67 \\
\hline Homeowner & 0.5215 & 4.31 & 0.5309 & 4.39 & 0.5011 & 4.14 \\
\hline Constant & -6.7853 & -0.7 & -7.7305 & -1.53 & -6.3378 & -0.66 \\
\hline $\begin{array}{l}\text { Number of } \\
\text { observations }\end{array}$ & 6788 & & 6788 & & 6788 & \\
\hline LF chi2(12) & 388.17 & & 389.57 & & 387.85 & \\
\hline Pseudo R2 & 0.0119 & & 0.0119 & & 0.0118 & \\
\hline
\end{tabular}

Note: Own calculations based on EVS 1998. Sample estimates are weighted to represent the German population.

Sample includes households with a head aged 65 and older.

\footnotetext{
${ }^{20}$ See table $2 \mathrm{a}$ in the appendix for the estimation results based on the East sample.
} 
The independent control variables mostly show the expected coefficients. Household heads who were never married or divorced have a lower probability of giving financial support to others than their married counterparts (reference category). The same holds for bigger households, while female household heads give more. Disposable household income proves to be the expected important determinant for giving transfers. The coefficient of the variable measuring financial wealth stays insignificant but homeownership is in the "old states" associated with a higher transfer probability.

The results in table 2 which explain the amount transferred are very similar, but the overall fit of the estimation is worse. Again, larger households, never married and divorced heads give smaller amounts and homeowners pay more - holding everything else constant. Income is expectedly the important determinant, i.e. the higher the disposable household income, the more money is transferred. In the new federal states income has a positive coefficient too as well as the dummy representing female household heads.

Here, the main purpose of these control variables is to isolate the impact of public transfers on the giving of private financial support. The estimation results in both tables show indeed a significant positive coefficient both for the amount of public transfers (probit 1) as well as for the share of public transfers in gross household income (probit 2$)^{21}$. The motivation for the second model stems from social policy analysis about the income situation of the elderly where this measure is commonly used. But before interpreting this result we should first look at the third estimation variant (probit 3), which uses a dummy specification in order to improve our understanding of the importance of public transfers for private transfers. In this version the unequal distribution of the public transfer share is considered by creating dummy variables instead of assuming a linear relationship between the share of public transfers in retirement income and the probability of making a private transfer. For many elderly households public transfers are the only income source (transfer dummy 1 equals 1 ). If households totally depend on public payments we would expect them to show a lower probability for granting a transfer because their total dependence on a monthly annuity should restrict their financial scope. On the other hand we hypothesized a lower transfer propensity for households with a small share of public transfers in the income package, too. For these households public transfers make up for less than 75 percent of total household income. About a quarter of the households in the age group considered belong to this group. The reference category (transfer dummy 2) finally refers to households receiving public transfers

\footnotetext{
${ }^{21}$ For the Eastern part of Germany this results hold for the probit but not the tobit estimation.
} 
in an average range. For these households we expect a higher propensity to give private transfers.

This specification yields the expected results in the probit as well as in the tobit model for the "old states". Households who totally rely on public financial support are less likely to grant private transfers. The same holds true for households which have considerable other income sources than public transfers. On the other hand we see that households that give transfers are characterized by a substantial share of public transfers in household income.

How can the positive influence of public transfers on the willingness to give private transfers be explained? In face of the high contribution rates that the working age generation has to pay to the pension system and the still generous general replacement rate it can be interpreted as a compensation device between the generations, as Barro postulated. From an economic perspective the backflow of resources from old to young is an inefficient detour system, mainly because high labour fringe costs impede economic growth. On the other hand sociologists argue that the impact of public on private transfers is a basis for crowding in: public transfers permit the elderly to award financial gifts to their adult children from which they can expect other support in return. Unfortunately, non-financial support cannot be observed in the EVS dataset that is used in this paper, but this effect was shown in figure 1, based on data taken from the Ageing Survey.

A second explanation could be that the elderly have been simply surprised by their high pension income and therefore give part of it to their children. Schnabel (2001) shows indeed that wage growth in the years of economic growth up to the 1970s was so large and unprecedented that the pensions for certain pensioner cohorts are even higher than their average labour income over the life-cycle.

A third explanation is related to the problem of missing variables. From another viewpoint the results show that households with more private old age provision are more reluctant to pay private transfers. ${ }^{22}$ This might simply be because they have to rely on their funded claims and wealth instead of enjoying guaranteed life-long public pension annuities.

\subsubsection{The receipt of private and public transfers by the elderly}

In this section we address the crowding out hypothesis by looking at financial transfers received by the elderly. Again, we start with some basic information about private transfer

\footnotetext{
${ }^{22}$ Unfortunately, the EVS data do not include the former occupational status for those already retired .
} 
receipt that can be drawn from the EVS database. As already seen in figure 1, the proportion of households with a head aged at least 65 years old that received a private financial transfer is much smaller than the share of households that make a private transfer. Only 9.6 percent of households in the "Old States" in that age group reported the receipt of a private transfer in 1998, compared with even fewer transfer recipients in the "New States" $(5.0 \%){ }^{23}$ The average transfer to the elderly augments to $7012 \mathrm{DM}^{24}$ which is more than the elderly give to other private households. One reason for this surprising result could be the receipt of bequests. The median transfer payment amounts to $3600 \mathrm{DM}$, which shows again the asymmetrical distribution that is shifted towards smaller transfers. ${ }^{25}$ The private payments are expectedly higher in the old than in the new German states (7636 DM resp. 5017 DM).

Looking at age and income as two important determinants of transfer receipt, we find a stable fraction of elderly receiving private transfers in Germany for all age classes, ranging from 9 to 11 percent. While the age pattern is similar in East and West Germany, the effect of the income is not. Figure 4 shows these differences for the old and new federal states very clearly.

\section{Figure 4: Transfer receipt by income quartiles}

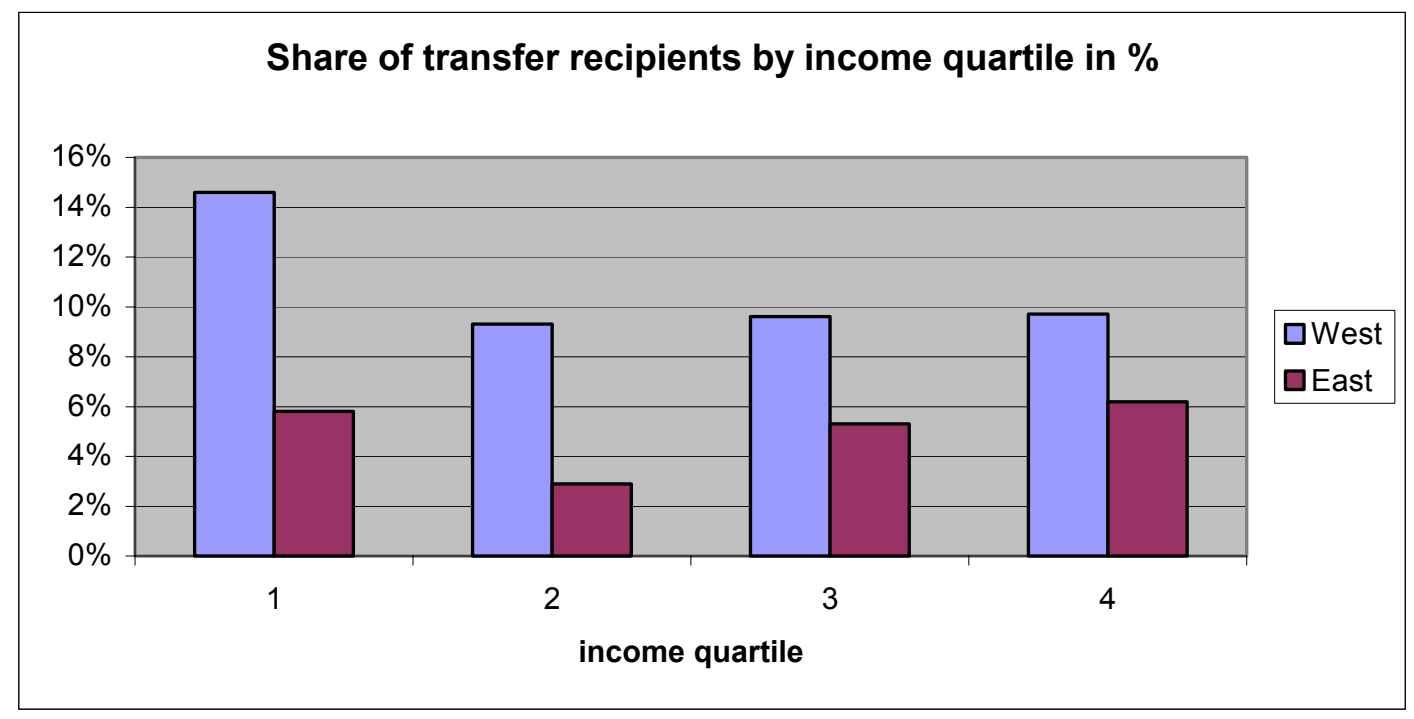

Note: Only household head aged at least 65. Underlying income is income without private transfer. Source: Own calculations based on EVS 1998.

The fraction of transfer receivers is the highest in the lowest income quartile in West Germany, but remains about constant among the remaining quartiles. We do not observe this pattern in the new federal states.

\footnotetext{
${ }^{23}$ Compare with "Five Nation Study": help out with money (65+): often 9.0\%, occasionally $14.8 \%$

${ }^{24}$ The average over all households with a head aged 65 or more amount to $671 \mathrm{DM}$.

${ }^{25}$ The lower $10 \%$ of the distribution are smaller than 456 DM while the top $10 \%$ are more than $14972 \mathrm{DM}$.
} 
Figure 5 shows the size of private transfers received by the elderly. The average transfer clearly increases over the quartiles of the income distribution. The top quartile receives about four times more than the bottom one. Those who already have more income also receive more in case of private support. We already know this pattern from empirical analysis of inheritances (e.g. Szydlik 2004).

Figure 5: Transfer amounts received by income quartiles

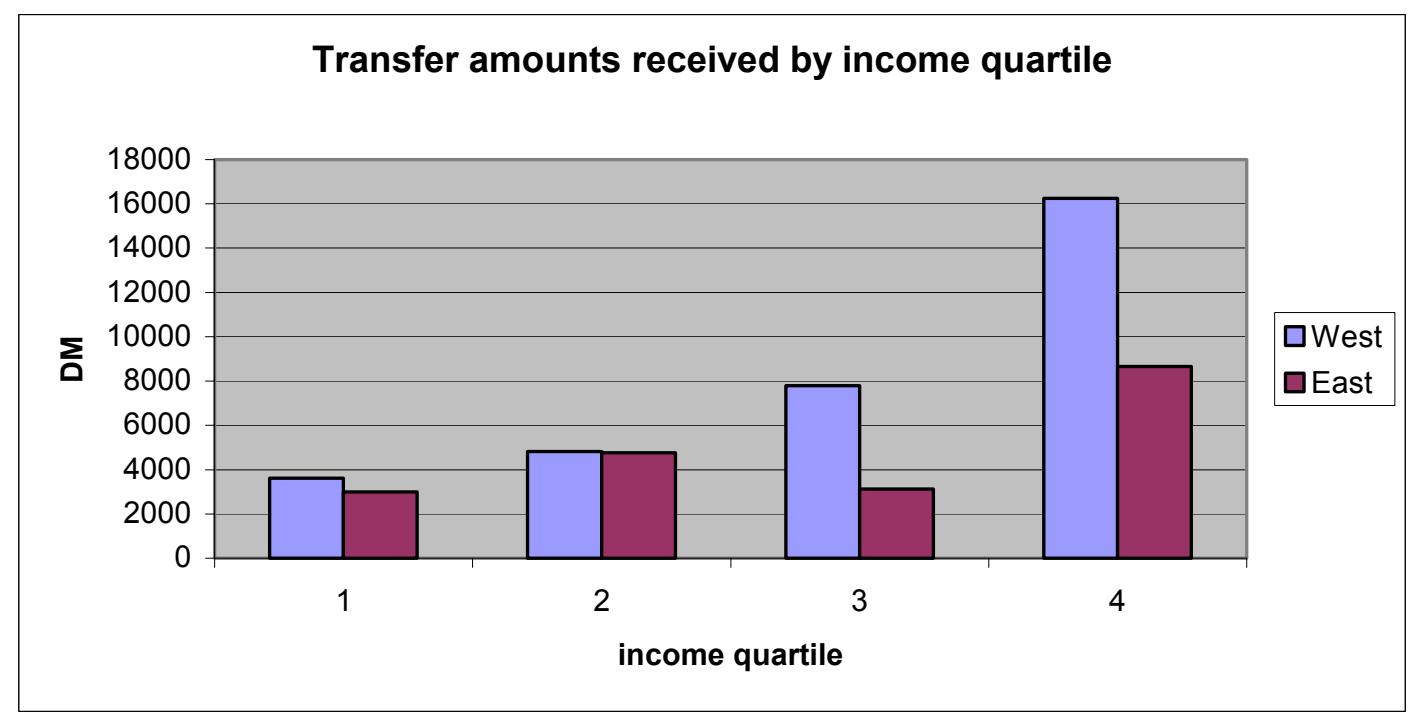

Note: Only household head aged at least 65. Underlying income is income without private transfers. Source: Own calculations based on EVS 1998.

We now test for the crowding-out hypothesis in the original sense that the provision of public financial support leads to a reduction of private financial help which would otherwise have been provided. Again, a probit and a tobit model are set up to estimate the probability of private transfer receipt respectively the amount received. We test the hypothesis that households who receive a larger fraction of public transfers are getting - ceteris paribus - less private transfers. Table 3 shows the results of the probit (probability of receiving a private transfer) and table 4 those of the tobit estimation (transfer amount). Detailed summary statistics of the variables are displayed in table $\mathrm{A}$ in the appendix. 
Table 3: Determinants of transfer receiving (West) ${ }^{26}$

\begin{tabular}{|c|c|c|c|c|c|c|}
\hline & \multicolumn{2}{|c|}{ Probit (1) } & \multicolumn{2}{|c|}{ Probit (2) } & \multicolumn{2}{|c|}{ Probit (3) } \\
\hline Variable & Coefficient & $\begin{array}{c}\text { z- } \\
\text { value }\end{array}$ & Coefficient & $\begin{array}{c}\text { z- } \\
\text { value }\end{array}$ & Coefficient & $\begin{array}{c}\text { z- } \\
\text { value }\end{array}$ \\
\hline Age & 0.0098 & 0.10 & 0.0872 & 0.87 & 0.098 & 0.10 \\
\hline Age squared & -0.0004 & -0.08 & -0.0005 & -0.79 & 0.0004 & -0.08 \\
\hline Household size & 0.2943 & 4.23 & 0.2046 & 2.75 & 0.3326 & 4.85 \\
\hline Female & 0.2921 & 4.09 & 0.3343 & 4.42 & 0.3009 & 4.22 \\
\hline Never married & -0.2456 & -2.04 & -0.3747 & -2.94 & -0.1727 & -1.45 \\
\hline Widowed & -0.1801 & -1.74 & -0.3301 & -3.00 & -0.1251 & -1.22 \\
\hline Married & Reference & - & Reference & & Reference & \\
\hline Divorced & 0.1293 & 1.13 & -0.0847 & -0.70 & 0.2343 & 2.09 \\
\hline $\begin{array}{l}\text { Living } \\
\text { Separately }\end{array}$ & 0.5362 & 3.32 & 0.2755 & 1.55 & 0.6222 & 3.89 \\
\hline $\begin{array}{l}\text { Disposable } \\
\text { Income (log) }\end{array}$ & -0.1417 & -2.22 & -0.7737 & $\begin{array}{r}- \\
15.41\end{array}$ & -0.7087 & $\begin{array}{r}- \\
14.47\end{array}$ \\
\hline $\begin{array}{l}\text { Public transfers } \\
(\log )\end{array}$ & -0.5374 & -9.15 & - & - & - & - \\
\hline $\begin{array}{l}\text { Public transfer } \\
\text { income share }\end{array}$ & - & - & 0.0244 & $\begin{array}{r}- \\
22.69\end{array}$ & & \\
\hline $\begin{array}{l}\text { Share of public } \\
\text { transfers }=1 \quad \text { (D) }\end{array}$ & - & - & - & - & -0.2961 & -5.51 \\
\hline $\begin{array}{l}\text { Share of publ. } \\
\text { transf. betw. } 1 \\
\text { and } 0.75\end{array}$ & - & - & - & - & Reference & - \\
\hline $\begin{array}{l}\text { Share of public } \\
\text { transf.<0.75, D. }\end{array}$ & - & - & - & - & 0.2753 & 5.20 \\
\hline Financial wealth & $3.86 e-07$ & 2.21 & $-1.41 e-07$ & -0.65 & $5.19 e-07$ & 3.13 \\
\hline Homeowner & -0.1333 & -2.92 & -0.2126 & -4.37 & -0.1358 & -2.98 \\
\hline Constant & 4.7725 & 1.33 & 3.9620 & 1.49 & 5.0670 & 1.41 \\
\hline $\begin{array}{l}\text { Number of } \\
\text { observations }\end{array}$ & 6788 & & 6788 & & 6788 & \\
\hline LF $\operatorname{chi2(12)}$ & 369.80 & & 846.32 & & 386.77 & \\
\hline Pseudo R2 & 0.0800 & & 0.1821 & & 0.0832 & \\
\hline
\end{tabular}

Note: Own calculations based on EVS 1998. Household income is pre-transfer income. Sample includes households with a head aged 65 and older. Sample estimates are weighted to represent the German population.

\footnotetext{
${ }^{26}$ See table 3a in the appendix for the estimation results based on the East sample.
} 
Table 4: Determinants of transfer amounts received (West) ${ }^{27}$

Tobit (1) Tobit (2)

Tobit (3)

Variable

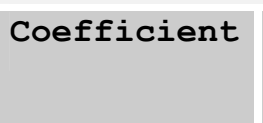

Age
Age squared
Household size
Female

Never married

3.7535
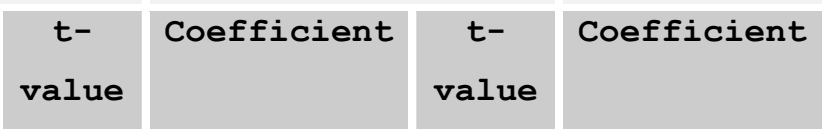

3.02

3.8473

3.42

3.2737

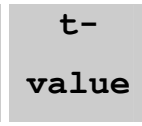

\begin{tabular}{|r|r|}
\hline-0.0238 & -2.88 \\
\hline 4.7125 & 5.10 \\
\hline
\end{tabular}

\begin{tabular}{|r|r|}
\hline-0.0244 & -3.25 \\
\hline 3.0271 & 3.63 \\
\hline
\end{tabular}

$-0.2049$

2.56

Widowed
Married

\begin{tabular}{|l|l|}
\hline 3.7457 & 3.99 \\
\hline 0.7110 & 0.46 \\
\hline
\end{tabular}

\begin{tabular}{|r|r|}
\hline 3.5521 & 4.16 \\
\hline-0.3518 & -0.25
\end{tabular}

5.7484 $-2.41$

\begin{tabular}{|r|r|}
\hline 2.4207 & 1.81 \\
\hline Reference & -
\end{tabular}

\begin{tabular}{r|r|}
1.1381 & 0.95 \\
\hline
\end{tabular}

Divorced

\begin{tabular}{|l|l|}
\hline 4.6706 & 3.15 \\
\hline 6.9517 & 3.37 \\
\hline
\end{tabular}

2.3473
1.8035

1.74
0.93

Living

Separately

Disposable
Income (log)

Public transfers

$-4.8934$
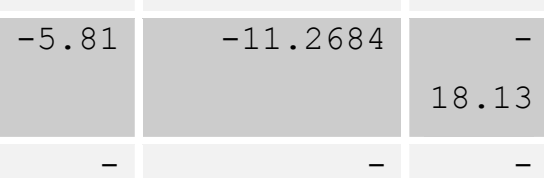

\begin{tabular}{|l|l|}
\hline 4.6897 & 4.81 \\
\hline 3.5599 & 2.24 \\
\hline
\end{tabular}

$(\log )$

10.78

Public transfer
income share
Share of public
transfers $=1$ (D)
Share of publ.
transf. betw. 1
and 0.75
Share of public
transf.<0.75, D.
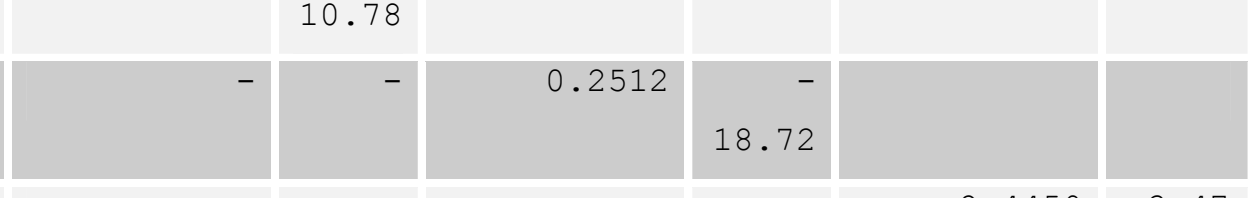

15.56

Financial wealth

\begin{tabular}{|r|r|}
\hline $2.82 e-06$ & 1.15 \\
\hline-2.8107 & -4.68 \\
\hline-31.8820 & -0.68 \\
\hline 6788 & \\
\hline
\end{tabular}

$\begin{array}{r}-2.93 e-06 \\ -3.2677 \\ -31.4452 \\ \hline\end{array}$

$-1.20$

\begin{tabular}{|r|r|}
\hline $6.08 e-08$ & 2.34 \\
\hline-2.4743 & -4.03 \\
\hline
\end{tabular}

Homeowner

1051.66

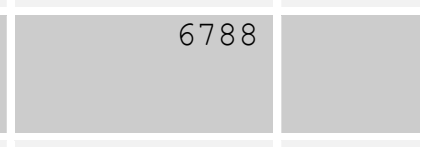

1432.64

$-146.84-3.06$

\begin{tabular}{|l|r|r|r|}
\hline $\begin{array}{l}\text { Number of } \\
\text { observations }\end{array}$ & 6788 & 6788 & 6788 \\
\hline LF chi2(12) & 1051.66 & 1432.64 & 386.77 \\
\hline Pseudo R2 & 0.1266 & 0.1714 & 0.0832 \\
\hline
\end{tabular}

Note: Own calculations based on EVS 1998. Household income is pre-transfer income. Sample includes households with a head aged 65 and older. Sample estimates are weighted to represent the German population.

\footnotetext{
${ }^{27}$ See table $4 \mathrm{a}$ in the appendix for the estimation results based on the East sample.
} 
The qualitative influence of the independent variables is about the same for the probability of receiving a transfer and for the size of the transfer. Larger households and women are more likely to receive a private transfer and to receive a larger amount. Divorced and separated heads of households have a higher propensity to receive private financial support, which might be explained by the inclusion of alimonies. ${ }^{28}$ Income has the expected negative sign in both estimations, i.e. the lower the income the higher is the probability of receiving financial support and of getting more. The estimations tend to show some positive impact for the variable measuring financial wealth, but it depends on the specification and thus is not very robust. Bequests to already wealthy households could be an explanation. Homeowners are clearly less likely to be supported and can expect only a smaller transfer amount than tenants.

The coefficient of the amount (1) and the share of public transfers in gross income (2) is significantly negative. Accordingly, the analysis clearly shows that the elderly who receive more public transfers cannot expect to receive private financial help on top. Hence, the hypothesis about an underlying crowding out process cannot be rejected. The alternative specification which is displayed in the third colum (3) of tables 3 and 4 supports this interpretation. The negative sign of the share of public transfers remains for the subgroup of households depending totally on public transfers. The public support they receive reduces the probability as well as the amount of private financial help. On the other hand we observe that households with a substantial share of own old-age provision receive bigger financial gifts from other private households. ${ }^{29}$

However, some limitations of these estimations have to be mentioned. Firstly, the estimations might suffer from the problem of omitted variables. In the underlying EVS data we cannot match givers and recipients. That means we can neither observe the characteristics of the transfer recipients when investigating the transfer giving, nor those of the givers when analysing transfer reception. But the financial resources of givers and receivers have to be proved as important determinants in former empirical studies about transfer behaviour (e.g. Motel 1997, Attias-Donfut and Wolff 2000). Special events as a reason for awarding private

\footnotetext{
${ }^{28}$ While legally enforced transfer do not occur in that age group as often as in the population as a whole (see section 3.2.1) they nevertheless occur in that age-group too. Unfortunately, the data set does not allow to separate between voluntary private transfers to the divorced/separately living and voluntary transfers to them because they are in need. As this sub-group is the one in which legally enforced transfers are the most likely I am controlling for the marital status in the regression in order to get an unbiased coefficient for the explanatory variable of main interest, the public transfers.

${ }^{29}$ One could argue that restrictions of public programs impede relatives to help the elderly in need as they would loose their claim for public support due to private assistance. But, in Germany, social assistance works differently: when claiming social assistance the income of the children and not the acutal transfer is considered.
} 
transfers cannot be covered with the EVS data either. ${ }^{30}$ Moreover, the frequency of contact and the emotional closeness between parents and children has been proved to be relevant (Motel und Szydlik, 1999). The same holds for liquidity constraints due to capital market imperfections which are eased by private transfers and are of concern for economists with respect to savings behaviour (Guiso and Jappelli 1991, Cox 1990). But, although these factors could not enter the analysis, the results are not expected to be distorted with respect to our central hypothesis because the left out variables are probably uncorrelated with the amount and fraction of public transfers in total income. However, the left out variables could be a reason for the overall unsatisfactory fit of the estimated model.

Secondly, we only considered financial transfers. But Kohli (1993) for instance argues that the state provision of an adequate income for elderly people may result in shifts to other forms of private support. For example, if there is less need to support the elderly financially because they have enough income or wealth, private transfers from the adult children would be expected to decline, while at the same time the level of private services can be expected to increase. Figure 1 showed such an unbalanced relationship between services and financial aid between parents and children.

\section{Conclusions}

Starting from Barro's thoughts about the relevance of private intergenerational relations for the public intergenerational allocation of resources, the relationship between private and public transfers was analysed in this paper.,Tthe empirical analysis about the impact of public transfers on private transfers of the elderly in Germany showed a strong connection between the family and the state. From the observation that received public transfers positively influence private transfer giving two conclusions can be drawn. Firstly, private payments act as a backflow of public intergenerational transfers and represent therefore an inefficient circular flow of resources. Secondly, reactions in private transfer behaviour to changes in pension policy can be expected. In light of the current pension reforms for instance aiming at a reduction of the public pension levels, a decrease of private financial support from the elderly to the young generation will be likely.

On the other side, we asked if the receipt of public financial transfers by the elderly crowds out private financial support they would otherwise obtain. We actually found a significant

\footnotetext{
${ }^{30}$ Jürges (1999) showed for instance that moving out of the parent's household increases the probability to get financial help (Jürges 1999). Bhaumik (2001) examines the significance of demographic and other events for transfer behaviour.
} 
negative influence of public transfers on the probability and the amount of receiving private financial help. This gives a clear hint to a crowding-out process which has to be considered when designing social security systems. The observation of an underlying crowding-out process in German data is in line with the prevalence of an altruistic notion as a transfer motive.

As the empirical analysis in this paper refers to financial transfers only, it does not necessarily contradict the sociological view of a "crowding in" process. Instead, the notion of Künemund and Rein (1999) that the relationship between public and private support might not be linear is supported. Therefore, crowding in and crowding out may occur at the same time. The results of this paper are in line with the argument that within an advanced welfare state like in Germany the wealthier receive non-financial support because they have something to return while the poorer elderly receive less private financial help when the state provides the income for their basic needs.

\section{References}

Attias-Donfut, C. and F.-C.: Wolff (2000): Complimentary between private and public transfers. In: S. Arber and C. Attias-Donfut: The Myth of Generational Conflict. The family and state in ageing societies. Routledge: London.

Barro, R. J. (1978): The Impact of Social Security on Private Saving. Evidence from U.S. Time Series. American Enterprise Institute Washington D.C.: 1-36.

Barro, R. J. (1974): Are Government Bonds Net Wealth? Journal of Political Economy 82: 1095-1117.

Becker, G. (1974): A theory of social interactions. Journal of Political Economy 82: 10631093.

Bernheim, D., A. Shleifer und L. Summers (1985): The strategic bequest motive. Journal of Political Economy 93: 1945-1076.

Bhaumik, S. K. (2001): Intergenerational transfers: The ignored role of time. MPIDR Working Paper 2001-008, Max-Planck Institute for Demographic Research, Rostock.

Börsch-Supan, A., A. Reil-Held und R. Schnabel (2002): Household Savings in Germany. In: A.Börsch-Supan (Hg.): Life Cycle Savings and Public Policy - A Cross National Study of Six Countries, Academic Press, New York.

Braun, R., F. Burger, M. Miegel, U. Pfeiffer and K. Schulte (2002): Erben in Deutschland. Deutsches Institut für Altersvorsorge (DIA), Köln.

Cox, D. and G. Jakubson (1995): The Connection between Public Transfers and Private Interfamily Transfers. Journal of Public Economics 57: 129-67. 
Cox, D. (1987): Motives for Private Income Transfers. Journal of Political Economy 95: 508546.

Croda, E. (1999): Sharing the wealth: An Empirical Analyis of Income Shocks and IntraFamily Transfers in Germany. Vierteljahreshefte zur Wirtschaftsforschung Heft 2: 184190.

Daatland, S. O. (2004): Comparative perspectives on the support of older people: State, market, and family contributions in an European context. Mimeo.

Jürges, H. (1999): Parent-Child-Transfers in Germany: A Study of Magnitude and Motivations, Zeitschrift für Wirtschafts- und Sozialwissenschaften 119 (3): 429-453.

Kohli, M. (1993): Public Solidarity between Generations: Historical and Comparative Elements. Free University of Berlin, Research Group on Ageing an the Life Course, Research Report 39.

Kohli, M., H. Künemund, A. Motel und M. Szydlik (2000a): Generationenbeziehungen. In: Kohli, M. und H. Künemund (Hg.): Die zweite Lebenshälfte. Gesellschaftliche Lage und Partizipation im Spiegel des Alters-Survey. Leske + Budrich, Opladen.

Kohli, M., H. Künemund, A. Motel and M. Szydlik (2000b): Intergenerational Transfers in East and West Germany. In: S. Arber and C. Attias-Donfut: The Myth of Generational Conflict. The family and state in ageing societies. Routledge: London: 88-99.

Kotlikoff, L. J. und A. Spivak (1981): The family as an incomplete annuties market. Journal of Political Economy 89: 372-91.

Künemund, H.(2002): Sozialstaatliche Leistungen und Familienbeziehungen im Alter Verdrängung oder Ergänzung?. In: Backes, Gertrud M. \& Wolfgang Clemens (Hrsg.): Zukunft der Soziologie des Alter(n)s. Opladen: Leske + Budrich, 167-181?

Künemund, H. and M. Rein (1999): There is more to receiving than needing: theoretical arguments and empirical explorations of crowding in and crowding out. Ageing and Society 19: 93-121.

Reil-Held, A. (2002): Die Rolle intergenerationaler Transfers in Einkommen und Vermögen der älteren Haushalte in Deutschland. MATEO, Universität Mannheim.

Schnabel, R. (2001): The Golden Years of Social Security - Life-cycle Income, Pensions and Savings in Germany" ,SFB 504 Discussion Paper 99-40, University of Mannheim.

Szydlik, M (2000): Lebenslange Solidarität? Generationenbeziehungen zwischen erwachsenen Kindern und Eltern. Opladen: Leske + Budrich.

Szydlik, M. (2004): Inheritance and Inequality: Theoretical Reasoning and Empirical Evidence. In: European Sociological Review, 20, 1: 31-45.

Wilk, C. (1995): Transferleistungen von Älteren - Expertise im Auftrag des Bundesministeriums für Familie. Bonn; BM für Familie, Senioren, Frauen und Jugend.

Motel-Klingebiel, A., Tesch-Römer, C., \& von Kondratowitz, H.-J. (2003). The Quantitative Survey. In Lowenstein, A., \& Ogg, J. (Hrsg.), OASIS - Old Age and Autonomy: The Role of Service Systems and Intergenerational Family Solidarity. Final report to the European Commission (pp. 63-101). Haifa: Haifa University. 


\section{Appendix}

\section{Table A:}

Sample description: summary statistics of independent and explanatory variables

\begin{tabular}{|c|c|c|c|c|}
\hline \multicolumn{5}{|c|}{ Old federal states } \\
\hline Variable & Mean & $\begin{array}{l}\text { Standard } \\
\text { deviation }\end{array}$ & $\begin{array}{l}\text { Mini } \\
\text { mum }\end{array}$ & $\begin{array}{l}\text { Maxi } \\
\text { mum }\end{array}$ \\
\hline Age & 73.8 & 5.53 & 65 & 85 \\
\hline Household size & 1.69 & 0.58 & 1 & 9 \\
\hline Female & 0.29 & 0.46 & 0 & 1 \\
\hline Married & 0.62 & 0.49 & 0 & 1 \\
\hline Never married & 0.07 & 0.26 & 0 & 1 \\
\hline Widowed & 0.36 & 0.48 & 0 & 1 \\
\hline Divorced & 0.98 & 0.30 & 0 & 1 \\
\hline Living separately & 0.02 & 0.13 & 0 & 1 \\
\hline Disposable income & 42,064 & 27,309 & 5,156 & 394,896 \\
\hline Disposable income net of priv. transfers & 41,239 & 26,822 & 2,000 & 394,896 \\
\hline Share of public transfers & 82.2 & 20.9 & 0 & 100 \\
\hline Financial wealth & 64,958 & 131,696 & $-208,121$ & $3,363,594$ \\
\hline Homeowner & 0.45 & 0.50 & 0 & 1 \\
\hline \multicolumn{5}{|c|}{ New federal states } \\
\hline Variable & Mean & $\begin{array}{l}\text { Standard } \\
\text { deviation }\end{array}$ & $\begin{array}{l}\text { Mini } \\
\text { mum }\end{array}$ & $\begin{array}{l}\text { Maxi } \\
\text { mum }\end{array}$ \\
\hline Age & 73.1 & 5.21 & 65 & 85 \\
\hline Household size & 1.46 & 0.55 & 1 & 5 \\
\hline Female & 0.51 & 0.50 & 0 & 1 \\
\hline Married & 0.41 & 0.49 & 0 & 1 \\
\hline Never married & 0.13 & 0.33 & 0 & 1 \\
\hline Widowed & 0.27 & 0.45 & 0 & 1 \\
\hline Divorced & 0.19 & 0.39 & 0 & 1 \\
\hline Living separately & 0.004 & 0.06 & 0 & 1 \\
\hline Disposable income & 32,580 & 14,489 & 9440 & 154,064 \\
\hline Disposable income net of priv. transfers & 32,327 & 14,283 & 9080 & 127,876 \\
\hline Share of public transfers & 95.3 & 9.9 & 0 & 100 \\
\hline Financial wealth & 26,215 & 34,330 & $-295,966$ & 444,789 \\
\hline Homeowner & 0.16 & 0.37 & 0 & 1 \\
\hline
\end{tabular}

Note: Sample based on the Income Consumption Survey 1998 (EVS) includes households with a head aged at least 65. All numbers are weighted to represent the German population. 
Table 1a: Determinants of transfer giving (East)

\begin{tabular}{|c|c|c|c|c|c|c|}
\hline & \multicolumn{2}{|c|}{ Probit (1) } & \multicolumn{2}{|c|}{ Probit (2) } & \multicolumn{2}{|c|}{ Probit (3) } \\
\hline Variable & Coefficient & $\begin{array}{c}\text { z- } \\
\text { value }\end{array}$ & Coefficient & $\begin{array}{c}\text { z- } \\
\text { value }\end{array}$ & Coefficient & $\begin{array}{c}\text { z- } \\
\text { value }\end{array}$ \\
\hline Age & 0.3051 & 2.13 & 0.3292 & 2.32 & 0.3183 & 2.23 \\
\hline Age squared & -0.0020 & -2.10 & -0.0022 & -2.29 & -0.0021 & -2.19 \\
\hline Household size & 0.2182 & -1.66 & -0.2224 & -1.64 & -0.2275 & -1.73 \\
\hline Female & 0.3361 & 3.20 & 0.3087 & 2.97 & 0.3263 & 3.10 \\
\hline Never married & -0.6345 & -3.57 & -0.6541 & -3.68 & -0.6587 & -3.73 \\
\hline Widowed & -0.2028 & -1.29 & -0.2014 & -1.28 & -0.2215 & -1.41 \\
\hline Married & Reference & & Reference & & Reference & \\
\hline Divorced & -0.39733 & -2.27 & 0.4684 & -2.71 & -0.4345 & -2.51 \\
\hline $\begin{array}{l}\text { Living } \\
\text { Separately }\end{array}$ & -0.9356 & -1.94 & -0.9278 & -1.92 & -0.9870 & -2.06 \\
\hline $\begin{array}{l}\text { Disposable } \\
\text { Income (log) }\end{array}$ & 0.0663 & -0.26 & 0.0122 & 3.22 & 0.4279 & 3.39 \\
\hline $\begin{array}{l}\text { Public } \\
\text { transfers (log) }\end{array}$ & 0.5262 & 1.99 & - & - & - & - \\
\hline $\begin{array}{l}\text { Public transfer } \\
\text { income share }\end{array}$ & & & 0.0075 & 2.25 & & \\
\hline $\begin{array}{l}\text { Share of public } \\
\text { transfers }=1 \\
\text { (D) }\end{array}$ & - & - & - & - & 0.085 & 0.09 \\
\hline $\begin{array}{l}\text { Share of publ. } \\
\text { transf. betw. } 1 \\
\text { and } 0.75\end{array}$ & - & - & - & - & Reference & - \\
\hline $\begin{array}{l}\text { Share of public } \\
\text { transf }<0.75 \\
\text { (D) }\end{array}$ & - & - & - & - & -0.1024 & 0.98 \\
\hline $\begin{array}{l}\text { Financial } \\
\text { wealth }\end{array}$ & $-1.81 e-06$ & 1.67 & $1.82 e-06$ & 1.65 & $1.79 e-06$ & 1.65 \\
\hline Homeowner & 0.02988 & 0.34 & 0.0883 & 0.34 & 0.0216 & 0.25 \\
\hline Constant & -15.98 & -2.91 & -12.73 & -2.41 & $-12 \cdot 68$ & -2.39 \\
\hline $\begin{array}{l}\text { Number of } \\
\text { observations }\end{array}$ & 1791 & & 1791 & & 1791 & \\
\hline LF chi2(12) & 67.38 & & 65.66 & & 65.57 & \\
\hline Pseudo R2 & 0.0293 & & 0.0286 & & 0.0285 & \\
\hline
\end{tabular}


Table 2a: Determinants of transfer amounts given (East)

Tobit (1)

Variable

Age
Age squared
Household size
Female, D.

Never married, D

Widowed, D.

Married, D.

Divorced, D.

Living

Separately, D.

Disposable
Income (log)

Public transfers

$(\log )$

Public transfer
income share
Share of public
transfers =1, D.
Share of publ.
transf. betw. 1
and 0.75
Share of public
transf.<0.75, D.

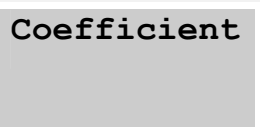

1.1827

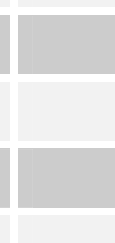

$-0.0076$

$-0.4082$

1.0847

$-1.9267$

0.1385

Reference

\begin{tabular}{|l|l|}
\hline-1.0017 & -1.78 \\
\hline-2.4007 & -1.46 \\
\hline
\end{tabular}

$-1.3045$

$-2.3809$

1.2825

$-0.0083$

$-0.3425$

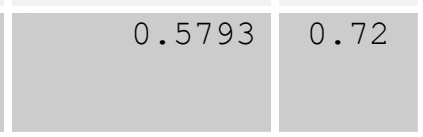

1.1392

1.36
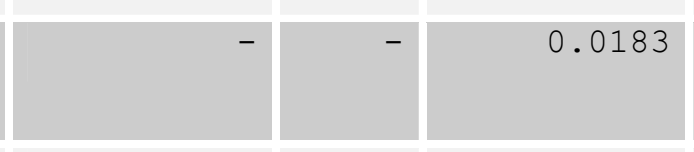

Financial wealth

Homeowner, D.

\begin{tabular}{|r|r|}
\hline $5.01 e-06$ & 1.61 \\
\hline 0.1218 & -0.44 \\
\hline
\end{tabular}

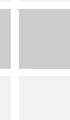

$5.40 e-06$
-0.1257

Number of
observations

LF chi2(12)

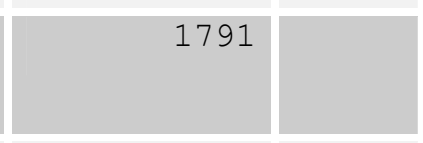

94.75

0.0106

Pseudo R2

Note: Own Calculations based on EVS 1998. Household income is pre-transfer income. Sample estimates are weighted to represent the German population. D. stands for "Dummy".

-2.36
-1.44

2.80

$-2.70$

$-0.81$
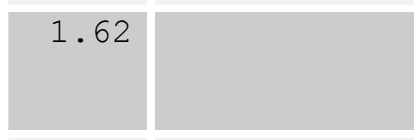

$-0.0569-0.20$

$-0.38$

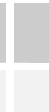

\begin{tabular}{|r|r|}
\hline$-5.10 e-06$ & 1.63 \\
\hline-0.1309 & -0.48 \\
\hline-58.66 & -3.41 \\
\hline
\end{tabular}

Tobit (3)

Coefficient

1.2022

2.63

$\begin{array}{lll}-0.0077 & -2.50\end{array}$

$-0.4150-0.99$

$-1.9742-3.49$

$-0.1715-0.35$

Reference

\begin{tabular}{l|l|}
-1.0654 & -1.92 \\
\hline-2.4889 & -1.52
\end{tabular}
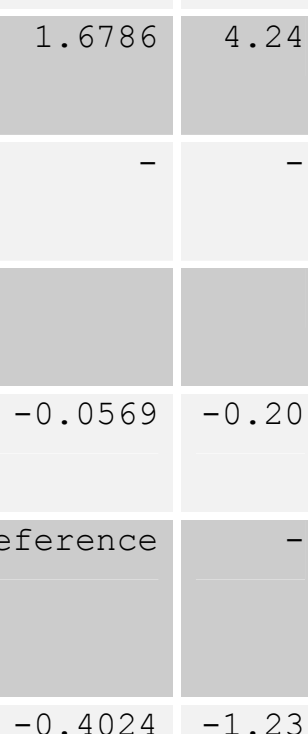

$-0.4024-1.23$

$-47.27-2.78$

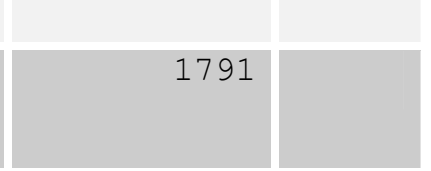

95.31

88.87

0.0107 
Table 3a: Determinants of transfer receiving (East)

\begin{tabular}{|c|c|c|c|c|c|c|}
\hline & \multicolumn{2}{|c|}{ Probit (1) } & \multicolumn{2}{|c|}{ Probit (2) } & \multicolumn{2}{|c|}{ Probit (3) } \\
\hline Variable & Coefficient & $\begin{array}{c}\text { z- } \\
\text { value }\end{array}$ & Coefficient & $\begin{array}{c}\text { z- } \\
\text { value }\end{array}$ & Coefficient & $\begin{array}{c}\text { z- } \\
\text { value }\end{array}$ \\
\hline Age & 0.1181 & 0.49 & 0.2267 & 0.88 & 0.6835 & 0.28 \\
\hline Age squared & -0.0008 & -0.49 & -0.0014 & -0.83 & -0.0004 & -0.28 \\
\hline Household size & 0.5016 & 2.79 & 0.4760 & 2.30 & 0.5355 & 2.96 \\
\hline Female & -0.1443 & -0.77 & -0.280 & -1.38 & -0.0798 & -0.42 \\
\hline Never married & 0.5367 & 2.02 & 0.4516 & 1.60 & 0.5378 & 2.01 \\
\hline Widowed & 0.1498 & 0.62 & 0.0396 & 0.15 & 0.1692 & 0.70 \\
\hline Married & Reference & - & Reference & & Reference & \\
\hline Divorced & 0.6450 & 2.42 & 0.4905 & 1.76 & 0.6671 & 2.52 \\
\hline $\begin{array}{l}\text { Living } \\
\text { Separately }\end{array}$ & 1.9506 & 3.77 & 1.4496 & 2.35 & 1.9709 & 3.84 \\
\hline $\begin{array}{l}\text { Disposable } \\
\text { Income (log) }\end{array}$ & 0.3453 & 0.82 & -0.00003 & -3.93 & -0.4387 & -2.16 \\
\hline $\begin{array}{l}\text { Public } \\
\text { transfers (log) }\end{array}$ & -0.7729 & -1.77 & - & - & - & - \\
\hline $\begin{array}{l}\text { Public transfer } \\
\text { income share }\end{array}$ & - & - & -0.4782 & $\begin{array}{r}- \\
10.46\end{array}$ & & \\
\hline $\begin{array}{l}\text { Share of public } \\
\text { transfers }=1 \\
\text { (D) }\end{array}$ & - & - & - & - & -0.3996 & -2.27 \\
\hline $\begin{array}{l}\text { Share of publ. } \\
\text { transf. betw. } 1 \\
\text { and } 0.75\end{array}$ & - & - & - & - & Reference & - \\
\hline $\begin{array}{l}\text { Share of public } \\
\text { transf }<0.75 \\
\text { (D) }\end{array}$ & - & - & - & - & -0.1293 & -0.79 \\
\hline $\begin{array}{l}\text { Financial } \\
\text { wealth }\end{array}$ & $-2.10 e-07$ & -0.12 & $-9.25 e-07$ & -0.45 & $-3.02 e-07$ & -0.16 \\
\hline Homeowner & -0.1755 & -1.09 & -0.2894 & -1.64 & -0.1396 & -0.87 \\
\hline Constant & -2.5243 & -0.28 & -5.9962 & -0.63 & -0.4467 & -0.05 \\
\hline $\begin{array}{l}\text { Number of } \\
\text { observations }\end{array}$ & 1791 & & 1791 & & 1791 & \\
\hline LF $\operatorname{chi2(12)}$ & 41.77 & & 148.99 & & 47.75 & \\
\hline Pseudo R2 & 0.0584 & & 0.2082 & & 0.0667 & \\
\hline
\end{tabular}


Table 4a: Determinants of transfer amounts received (East)

Tobit (1)

Variable

Age

Age squared
Household size
Female

Never married

Widowed

Married

Divorced
Living
Separately
Disposable
Income (log)

Public transfers $(\log )$

Public transfer
income share

Share of public

transfers $=1$ (D)

Share of publ.
transf. betw. 1
and 0.75
Share of public
transf.<0.75, D.

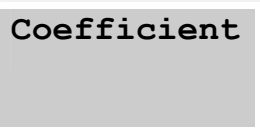

15.6268

\begin{tabular}{|r|r|}
\hline-0.1007 & -3.69 \\
\hline 10.9690 & 3.94 \\
\hline
\end{tabular}

\begin{tabular}{|r|c|}
\hline-3.3669 & -1.19 \\
\hline 13.7445 & 3.34 \\
\hline
\end{tabular}

$-3.7132$

9.2055

\begin{tabular}{|r|r|}
\hline 9.0723 & 2.54 \\
\hline Reference & -
\end{tabular}

4.9723
Reference

\begin{tabular}{|l|l|}
\hline 11.3852 & 2.69 \\
\hline 24.1893 & 3.21 \\
\hline
\end{tabular}

\begin{tabular}{|l|l|}
\hline 7.6609 & 2.35 \\
\hline 8.9308 & 1.40 \\
\hline
\end{tabular}

2.81

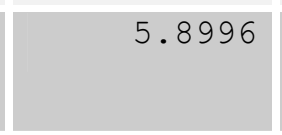

$-26.7802$

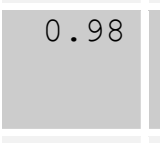

$-3.98$
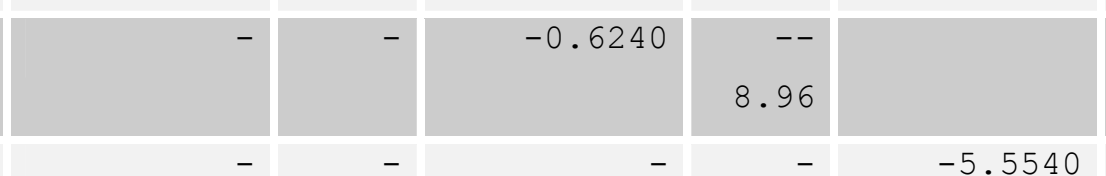

$-5.5540-2.60$
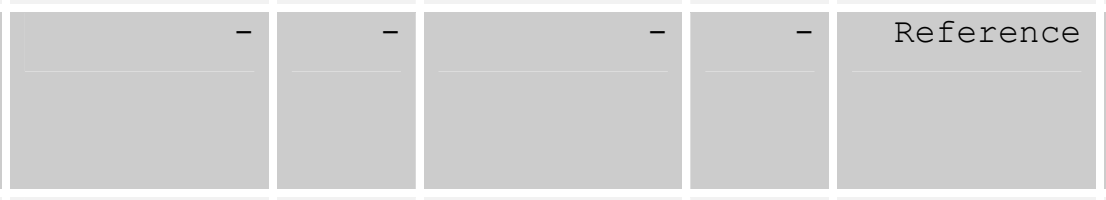

1. 4538

0.62

Financial wealth

Homeowner

Constant

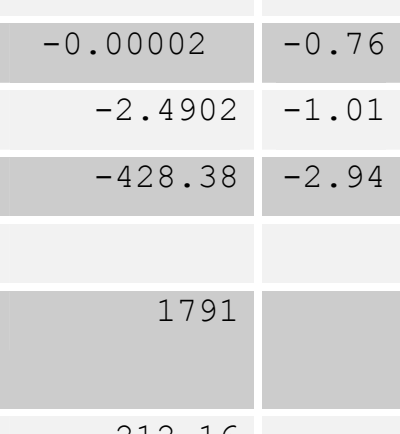

212.16

0.1533

\begin{tabular}{|r|r|}
\hline$-8.37 e-06$ & -0.37 \\
\hline-2.6515 & -1.37 \\
\hline-404.81 & -3.44 \\
\hline
\end{tabular}

\begin{tabular}{|r|r|}
\hline-0.00003 & -0.87 \\
\hline-1.6781 & -0.69 \\
\hline-374.15 & -2.56 \\
\hline
\end{tabular}

Number of
observations

LF $\operatorname{chi2(12)~}$

Pseudo R2

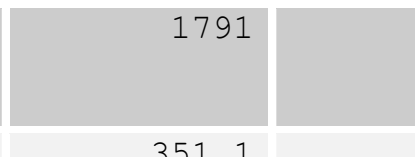

351.1

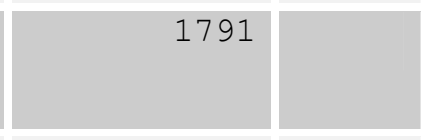

211.68

Note: Own Calculations based on EVS 1998. Household income is pre-transfer income. Sample includes households with a head aged 65 and older.Sample estimates are weighted to represent the German population. 


\section{Discussion Paper Series}

Mannheim Research Institute for the Economics of Aging Universität Mannheim

To order copies, please direct your request to the author of the title in question.

\begin{tabular}{|c|c|c|c|}
\hline Nr. & Autoren & Titel & Jahr \\
\hline $61-04$ & Barbara Berkel & $\begin{array}{l}\text { Institutional Determinants of International Equity } \\
\text { Portfolios - A County-Level Analysis }\end{array}$ & 04 \\
\hline $62-04$ & $\begin{array}{l}\text { Barbara Berkel } \\
\text { Axel Börsch-Supan }\end{array}$ & $\begin{array}{l}\text { Pension Reform in Germany: The Impact on } \\
\text { Retirement Decisions }\end{array}$ & 04 \\
\hline $63-04$ & Axel Börsch-Supan & From Traditional DB to Notional DC Systems & 04 \\
\hline $64-04$ & $\begin{array}{l}\text { Axel Börsch-Supan } \\
\text { Alexander Ludwig } \\
\text { Joachim Winter }\end{array}$ & $\begin{array}{l}\text { Aging, Pension Reform, and Capital Flows: A } \\
\text { Multi-Country Simulation Model }\end{array}$ & 04 \\
\hline $65-04$ & Axel Börsch-Supan & $\begin{array}{l}\text { Faire Abschläge in der gesetzlichen } \\
\text { Rentenversicherung }\end{array}$ & 04 \\
\hline $66-04$ & $\begin{array}{l}\text { Alexander Ludwig } \\
\text { Alexander Zimper }\end{array}$ & $\begin{array}{l}\text { Rational Expectations and Ambiguity: A Comment } \\
\text { on Abel (2002) }\end{array}$ & 04 \\
\hline $67-05$ & $\begin{array}{l}\text { Axel Börsch-Supan } \\
\text { Anette Reil-Held }\end{array}$ & $\begin{array}{l}\text { Die ökonomischen Auswirkungen der Alterung in } \\
\text { Hessen }\end{array}$ & 05 \\
\hline $68-05$ & $\begin{array}{l}\text { Axel Börsch-Supan } \\
\text { Alexander Ludwig } \\
\text { Anette Reil-Held }\end{array}$ & $\begin{array}{l}\text { Projection methods and scenarios for public and } \\
\text { private pension information }\end{array}$ & 05 \\
\hline $69-05$ & Axel Börsch-Supan & Risiken im Lebenszyklus & 05 \\
\hline $70-05$ & Hendrik Jürges & $\begin{array}{l}\text { Die ökonomische Theorie der Familie und die } \\
\text { Erklärung von Erbschaftsregeln - ein } \\
\text { problemorientierter Überblick }\end{array}$ & 05 \\
\hline $71-05$ & $\begin{array}{l}\text { Marcel Erlinghagen } \\
\text { Karsten Hank }\end{array}$ & $\begin{array}{l}\text { Participation of Older Europeans in Volunteer } \\
\text { Work }\end{array}$ & 05 \\
\hline $72-05$ & Anette Reil-Held & $\begin{array}{l}\text { Crowding out or crowding in? } \\
\text { Public and private transfers in Germany }\end{array}$ & 05 \\
\hline
\end{tabular}

